\title{
Wave-piercing Catamaran Transom Stern Ventilation Process
}

\author{
Max Haase, Jonathan Binns, Giles Thomas and Neil Bose
}

$14 / 07 / 2016$

\begin{abstract}
An investigation into the transom characteristics in the wake of the transom stern to ensure that numerical tools, used ventilation of hull forms with a deep transom, such as a wave-piercing catamaran, is reported. The new class of highly fuel-efficient medium-speed catamarans operate at speeds where the transom is partially or fully ventilated. It is important to understand the flow for resistance prediction, are accurately resolving the complex flow phenomena. Unsteady Reynolds-Averaged Navier Stokes simulations were used to simulate the flow around a $98 \mathrm{~m}$ catamaran, at both model and full scale, and the first compared to model test results for a 1:22 scale model. A non-shedding squashed horseshoe vortex was found to build up in the stagnant zone past the vessel, with the transom running dry at transom draft Froude numbers of 2.5 in model test experiments and at transom draft Froude numbers of 2.4 in numerical simulations at the same scale. For full-scale Reynolds numbers the full ventilation occurred at transom draft Froude numbers of 2.2. Furthermore, it is shown that unsteady Reynolds-Averaged Navier Stokes simulations are capable of accurately predicting the recirculating flow in the wake of the vessel and the resulting state of transom ventilation. Consequently this approach was used to visualise the flow features during the quasi-steady ventilation process.
\end{abstract}


List of Figures 


\section{Nomenclature}

Roman

$A_{i}$

$A_{T}$

$b$

$A_{T W}$

$B_{T}$

Fr

$\mathrm{Fr}_{T}$

$\mathrm{Fr}_{T}{ }^{*}$

$g$

$h$

$l$

$L$

$n_{x}$

$T_{T}$

$\operatorname{Re}_{T}$

$U$

V

$x, z$

\section{Greek}

$\alpha$

$\eta_{d r y}$

$v$

face area of numerical mesh cell

[m $\left.{ }^{2}\right]$

transom area

towing tank width

[m $\left.{ }^{2}\right]$

wetted transom area

[m]

transom width

[m $\left.{ }^{2}\right]$

[m]

length Froude number [-]

transom draft Froude number [-]

critical transom draft Froude number for [-]

full ventilation

gravitational constant, 9.81

towing tank depth

$\left[\mathrm{m} / \mathrm{s}^{2}\right]$

[m]

towing tank length

[m]

ship length

[m]

longitudinal normal vector

$[-]$

transom Reynolds number

[-]

flow velocity

$[\mathrm{m} / \mathrm{s}]$

ship velocity

$[\mathrm{m} / \mathrm{s}]$

ship coordinates

[m]

volume fraction

$[-]$

transom ventilation state

$[-]$

kinematic viscosity

$\left[\mathrm{m}^{2} / \mathrm{s}\right.$ ] 


\section{Introduction}

Large medium-speed catamarans, when compared to high-speed catamarans, will be larger in length and displacement, but operating at lower speeds; thus requiring different design principles. Transom sterns are popular features for fast ships as it reduces the resistance at Froude numbers of $F r>0.5$, but can increase the drag for speeds below as shown by O'Dea et al. (1981); Hadler et al. (2009); Haase et al. (2015b). However, a transom stern simplifies the vessel's construction (Schneekluth and Bertram, 1998), and it is convenient for accommodating waterjet propulsors (Doctors et al., 2007; Davidson et al., 2011). Whilst a deep transom is a popular feature for high-speed catamarans, it may not be beneficial for this new class of vessels as they operate at lower Froude numbers, and therefore it is necessary that its effect on the hull is accurately replicated in resistance prediction methods.

In an earlier study (Haase et al., 2012b) it was shown that RANS methods are capable of predicting calm water resistance of medium-speed catamarans for both dry and wet transoms, but also that deviations at low Froude numbers occur when compared to measured data. Build-up of a rooster tail at high speeds and a complex recirculation at low speeds were found, but the accurate prediction of the transition process from fully wet to a fully dry transom was not considered.

\subsection{Transom Stern Flow Predictions}

The flow regime of a surface vessel is usually expressed in terms of length Froude number ( $F r=V / \sqrt{g \times L}$ ), $V$ is the ship's velocity, $g$ the gravitational constant and $L$ the ship's waterline length. To characterise the flow past a transom it is appropriate to express it with respect to transom draft Froude

number $\left(F r_{T}=V / \sqrt{g \times T_{T}}\right)$ where $T_{T}$ is the draft of the transom with the vessel stationary. Studies by various researchers (Robards and Doctors, 2003; Maki et al., 2006) have shown that the transom reaches a 
dry state at $F r_{T}^{*} \approx 2.5$. This value may depend on the stern shape of the hull, its wave-making characteristics, the Reynolds number and dynamic sinkage and trim.

The accurate prediction of the flow past a transom stern of a surface vessel has been of interest for many years. This is primarily due to the significance of the transom flow patterns on the estimate of the resistance force by including the influence on the wave-making, such as studied by Doctors et al. (2007). In addition, the wake generates a highly unsteady flow field, including entrained air, which is an issue for defence vessels if detection is to be avoided. Hence the flow characteristics need to be modelled to a very fine extent (Hendrickson et al., 2013). The following paragraphs summarise the main achievements in modelling and predicting transom flows.

\subsubsection{Experimental Approaches}

Transom ventilation was experimentally studied for semi-palning catamarans by Oving (1985) who formulated that the dry state will occur at $F r_{T}^{*}=1.95$ with corrections for. Hadler et al. (2007) presented model test observations of his own experiments, those of Sireli et al. (2000) who utilised NPL hulls, and those of Kiss and Compton (1989) who used Combatant hulls. Based on these studies a critical transom depth Froude number at which the transom runs dry was derived as a function of $B_{T} / T_{T}$. For $1<B_{T} / T_{T}<3.5$ they predicted a dry transom between $2<F r_{T}^{*}<2.5$, where increasing $B_{T} / T_{T}$ values led to higher values of critical transom draft Froude number.

Robards and Doctors (2003) and Doctors et al. (2007) used the Baby series, hulls with constant rectangular cross sections and parabolic waterlines at the bow, to derive an empirical formulation to express the ventilation with respect to transom draft Froude number, $B_{T} / T_{T}$, and transom draft Reynolds

number $\left(\operatorname{Re}_{T}=\sqrt{g \times T_{T}^{3}} / v\right)$. They found that the influence of the transom draft Reynolds number on the ventilation process at the model scale range was small. Alternative coefficients for the empirical formulation were derived for a destroyer hull form by Maki (2005), who also studied the free surface flow past a backward facing step to estimate the flow characteristics of an infinitely wide transom (Maki et al., 
2006). Four flow regimes were identified and are presented in Figure 1. A stagnant area behind the transom that connects through a shear layer to the passing flow (regime A); with transom draft Froude number exceeding unity a distinctive vortex shedding was observed (regime B); reaching a critical transom Froude number where the transom goes dry and a breaking roller forms behind the separation point characterises the next regime (regime C); with further increasing transom Froude number this breaking roller moves further backwards and finally disappears (regime D). In the same study the process of ventilation was in agreement with the empirical formulation postulated by Doctors et al. (2007).

\section{fig01_transomRegimes.jpg}

Figure 1: Transom flow regimes as identified by Maki (2005) A: $F r_{T}<1$ resulting in a stagnant recirculating flow area that is separated by a shear layer. B: $1<F r_{T}<F r_{T}^{*}$ produces an unsteady vonKarman street with large surface fluctuations. C: $F r_{T}>F r_{T}^{*}$ leads to a dry transom and a breaking roller building up behind separation point. D: $F r_{T}<<F r_{T}^{*}$ so that the breaking roller past the separation disappears.

\subsubsection{Computational Approaches}

Fluid flow solvers that resolve the flow domain by subdividing it into small control volumes and take viscous effects into account are potentially capable of correctly simulating flows past transom sterns. Lin and Percival (2001) computed the flow around two bare hull transom stern combatant vessels using a steady RANS solver (Reynolds-averaged Navier Stokes) and implemented a kinematic boundary condition on the free surface to take wave elevations into account. The ability of the method to predict whether the transom was wet, dry or partially wet was reported. 
Wilson et al. (2006) used an unsteady RANS solver to compute the flow around the bare hull of the $\mathrm{R} / \mathrm{V}$ Athena and found periodic vortex shedding at the transom edge for partially wetted states. Eslamdoost et al. (2015) used unsteady RANS and experiments to study the influence of transom clearance on the drag force for a hard chine planing hull and identified that entering the full ventilation state coincides with the peak in resistance coefficient curve. Maki (2005) computed the flow past a free surface backward facing step using a 2D unsteady RANS solver utilising a level set approach to capture the free surface effects. Starke et al. (2007) used a 2D steady-state surface-fitting RANS approach to simulate the free surface flow past a backward facing step for Reynolds numbers correlating to both model and full scale vessels. Comparing their computed surface elevation with experimental data from Maki (2005) they obtained accurate solutions for partially and fully ventilated transoms. Scale effects were found such that full ventilation was predicted to occur at lower transom draft Froude number $\left(F_{T}^{*}=2.0\right)$ for full scale Reynolds numbers, compared to model scale Reynolds number (where $F r_{T}^{*}=2.5$ ). Wyatt et al. (2008) compared two codes, one being a RANS/DES (detached eddy simulation) code using a single phase, level-set method, the other a Cartesian Euler code. Average breaking wave height and corresponding RMS values (root-mean-square) of its fluctuation as well as the frequency domain in the flow past the transom of $\mathrm{R} / \mathrm{V}$ Athena were simulated at full scale and compared to full-scale measurements and good overall agreement was reported. The von-Karman-type vortex shedding for a wetted transom was shown using the RANS/DES solver for model and full-scale simulations of the fully appended vessel. Bhushan et al. (2012) investigated vortex structures and instabilities past the wetted transom of the fully appended R/V Athena in full scale and model scale. Using the solvers utilised in the above study, RANS was able to resolve coherent vortex shedding while the DES simulation could resolve much more detailed flow structures. The RANS/DES solver was capable of explaining the wake unsteadiness with the von-Karman-type vortex shedding. Lately, researchers have concentrated on the air entrainment in the wake of a transom stern ship using implicit LES (large eddy simulation) simulations, such as Hendrickson et al. (2013) who investigated the wake past a dry transom. The above studies 
indicate that a considerable amount of research has been conducted during the last decade to investigate steady and unsteady effects of the flow around a transom stern, However, it was mostly studied on combatant or planing craft hull forms that have a relatively high $B_{T} / T_{T}$ ratio, which exceeds that of a typical wave-piercing catamans and hence the three-dimensional structure of the flow in the stagnant zone past a partially ventilated transom is not understood.

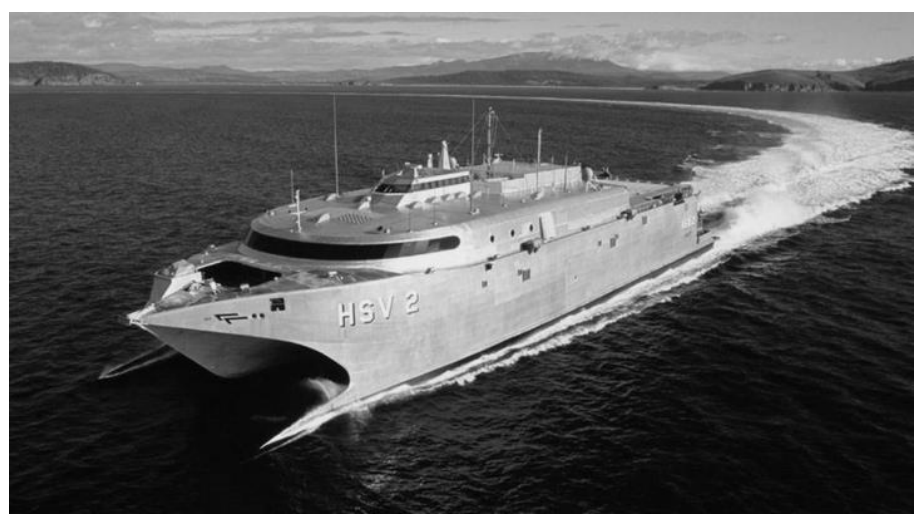

Fig02_98_BW.jpg

Figure 2: Image of the 98 m INCAT high-speed catamaran.

\subsection{Scope of Study}

In this study the flow characteristics past a partially ventilated transom were studied numerically and experimentally to quantify the state of transom ventilation at different speeds. A scale model of a $98 \mathrm{~m}$ wave-piercing catamaran (Figure 2) was used at low to medium speeds of $0.2<F r<0.4$. Compared to previously mentioned studies the current hull has a relatively low $B_{T} / T_{T}$ ratio of 1.3 . This research aims to assess the capability of unsteady RANS simulations to correctly predict the flow features occurring inside the zone of stagnant flow behind a transom stern. In particular whether an standard mesh resolution 
is sufficient or if special attention to local mesh refinements is required in this flow region. Furthermore, there is the desire to quantify differences in transom ventilation between model and full-scale Reynolds numbers. Numerical simulations were validated experimentally using quantitative and qualitative measures, including the level of transom ventilation and visualised flow features. 


\section{Methodology}

\subsection{Numerical Set-up}

In this study an unsteady RANS solver interDyMFoam from the OpenFOAM toolbox 2.3 utilising a volume of fluid method (VOF) was used to simulate the flow around the vessel. The solver is capable of resolving viscous free-surface flows and the changing attitude of the vessel. $k-\omega-S S T$ turbulence model and standard wall functions were applied to model the flow in close proximity to the hull.

The mesh was generated with the OpenFOAM tools blockMesh, snappyHexMesh, and refineMesh. Normal to the hull, a first cell hight of $0.6 \times L \times 10^{-3}$ was chosen, which was shown to deliver accurate shear stress predictions for model-scale and full-scale Reynolds numbers when a wall function is used (Haase et al., 2015c). The mesh comprised of 910k cells, which provided a deviation below $1 \%$ from a general Richardson-extrapolated value based on meshes of $660 \mathrm{k}, 910 \mathrm{k}$ and $1.28 \mathrm{M}$ cells at Froude numbers of 0.37 and 0.45 . No special refinement was made in the transom area (Figure 10). The inflation layer was 4 cells thick and the resulting $y^{+}$value ranged from around 200 in model scale to around 10,000 in full scale.

The state of partial transom ventilation was computed from the ratio of wetted transom area $\left(A_{T W}\right)$ over total transom area $\left(A_{T}\right)$. As expressed by:

$$
A_{T W}=\sum\left(-n_{x i} \times \alpha_{i} \times A_{i}\right) \forall x \leq x_{\text {transom }}
$$

and

$$
A_{T}=\sum\left(-n_{x i} \times A_{i}\right) \forall x \leq x_{\text {transom }} \wedge \mathrm{z} \leq 0
$$

$\alpha$ characterises the volume fraction where 1.0 denotes full of water and 0.0 denotes devoid of water, $n_{x}$ the longitudinal component of the normal vector and $A_{i}$ the area the cell face attached to the hull. Hence the transom ventilation is expressed as: 
$\eta_{d r y}=1-A_{T W} / A_{T}$

\subsection{Experimental Set-up}

The investigation on the flow past a partially ventilated transom stern was undertaken on a single demihull of a 1:22 scale model of a $98 \mathrm{~m}$ wave-piercing catamaran at a 1,500 tonnes displacement at level trim. The experiments were carried out in the towing tank of the Australian Maritime College (AMC) at the University of Tasmania having the dimensions of $l \times b \times h=100 \mathrm{~m} \times 3.55 \mathrm{~m} \times 1.50 \mathrm{~m}$, using a carbon fibre scale model. The transom features a trim tab that was deflected to 5 degrees and the model was free to heave and trim. The demihull interaction was taken into account by evaluating a single demihull in close proximity to a wall, at a distance equal to half the demihull separation. This approach was previously employed by Rovere (1997) and Zürcher et al. (2013).

The water level at the transom and at the side of the hull was measured visually using rulers with 5 $\mathrm{mm}$ increments attached to the transom stern as can be seen in Figure 4. To determine the characteristic structures of the flow in the stagnant area behind the transom, polyester stream traces (audio tapes) were attached to the inside of the trim tab and the side hull extensions. A total of 16 polyester tracers were utilised with a thickness of $0.1 \mathrm{~mm}$, width of $10 \mathrm{~mm}$ and a length of $240 \mathrm{~mm}$ each. The observations were made using three commercially available water proof video cameras from GoPro and Contour, which are highlighted in Figure 3. One camera was mounted above the stern to monitor the flow past the stern from above the water surface. Another was mounted under water to record the level of ventilation and the flow structures. Finally, the third camera was set up below the transom pointing upwards to videotape the structure of the flow recirculation in the horizontal plane. In addition, the drag force has been measured.

The transom ventilation was determined as the ratio of the water level at the aft of the port side wall of the port demihull and the water level at the transom. In contrast to the numerical model, the origin of the vertical axis was ship fixed and originates at the trailing edge of the stern tab, positive pointing up. Thus the ventilation state was determined as: 
$\eta_{d r y}=1-z_{\text {side } \text { wall }} / z_{\text {transom }}$

\section{Fig03_expSetUp.jpg}

Figure 3: Experimental set up in the $A M C$ towing tank. A single catamaran demihull is towed in close proximity to the tank wall. Futhermore, the cameras used and the stream traces are indicated.

\subsection{Empirical Prediction Method}

Doctors et al. (2007) performed a series of model tests on generic hull forms using the so-called Baby series to derive a regression model for predicting the state of transom ventilation as a function of transom Froude number based on transom draft at rest, with and without taking the transom breadth over transom depth ratio $\left(B_{T} / T_{T}\right)$ into account. Transom ventilation was determined as follows:

$\eta_{d r y}=C_{1} \times F r_{T}^{C_{2}} \times\left(B_{T} / T_{T}\right)^{C_{3}}$

with values for $C_{i}$ being $C_{i}=(0.08057,2.381,0)$ for the infinitely wide transom (2D) and $C_{i}=(0.07340,2.8356,0.1247)$ when taking $B_{T} / T_{T}$ into account (3D) for $1<B_{T} / T_{T}<4$. 


\section{Validation of Transom Flow}

\subsection{Physical Model Tests}

The model was tested for length Froude numbers of 0.20 to 0.40 in 0.02 increments. The water level at the transom was measured at each run. Figure 4 shows the transom at three different speeds: $F r=0.24,0.30$ and 0.36 , corresponding to transom draft Froude numbers of $F r_{T}=1.56,1.97$ and 2.38. The state of ventilation, $\eta_{d r y}$, is $0.24,0.55$ and 0.95 respectively. A complex small-scale flow structure can be observed for $F r=0.24$, which transits towards a rooster tail at $F r=0.30$ where the white portions in the wake can be addressed to wave-breaking. At $F r=0.36$, a rooster tail was observed, which clearly breaks to both sides and also sheds portions of water towards the transom. Finally the transom reaches the dry state at $F r=0.38$ corresponding to $F_{T}^{*}=2.50$. The dry state for all conditions under consideration can be seen in Figure 5, where the error bars represent the smallest increment on the ruler.

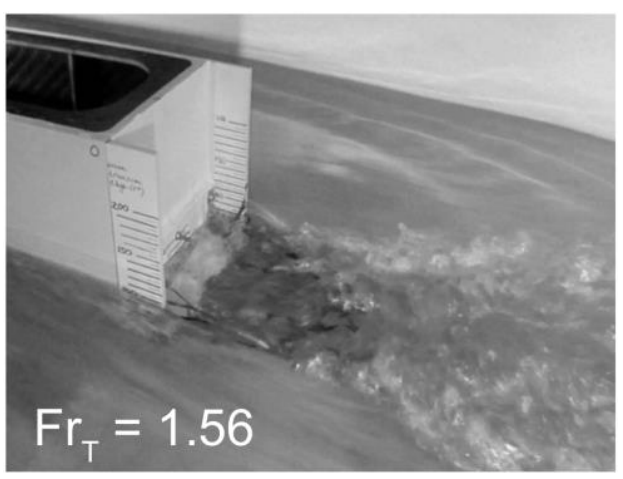



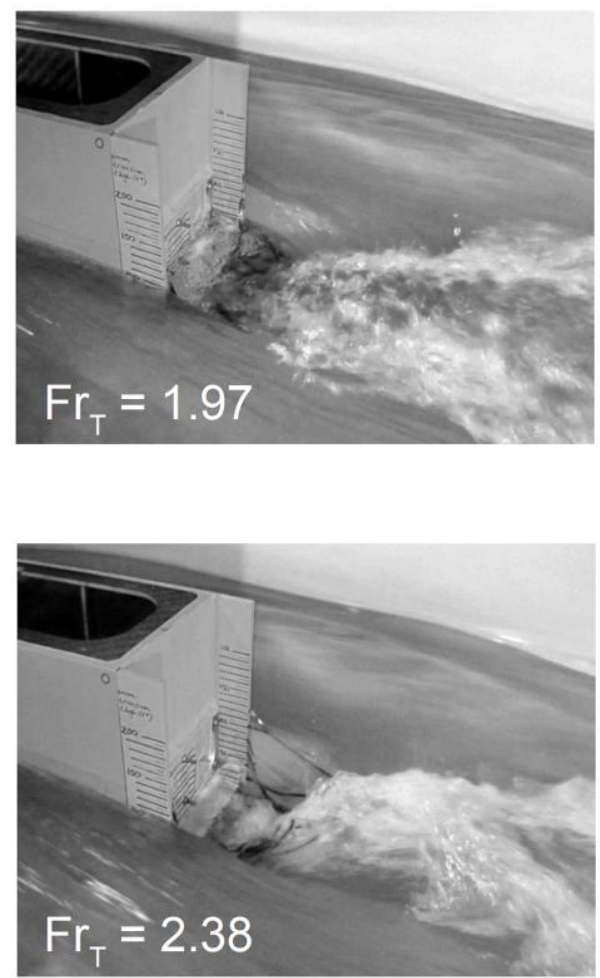

Fig4a_transomTopSideFrT156.jpg

Fig4b_transomTopSideFrT197.jpg

Fig4c_transomTopSideFrT238.jpg

Figure 4: Flow past the transom at different speeds of Froude numbers of $F r=0.24,0.30$ and 0.36 , corresponding to transom draft Froude numbers of $F r_{T}=1.56,1.97$ and 2.38.

\subsection{Numerical Prediction at Model Scale}

The experiments were replicated using CFD at identical displacement and speeds. The dry state $\left(\eta_{d r y}>0.99\right)$ was reached at $F r_{T}^{*}=2.42$, which corresponds to an under-prediction of dry state transom draft Froude number of 3\%. When comparing this result to Eslamdoost et al. (2015), where the RANS- 
based simulation predicted the dry state at a 5\% lower length Froude number, the result can be considered as being acceptably accurate.

Figure 5 shows the transom ventilation state for increasing transom draft Froude numbers predicted by numerical simulation and empirical expressions, and measured in model test experiments. For the CFD predictions no error was specified, even though it was observed that the transom ventilation fluctuated over time, the fluctuation was found to be $\pm 1 \%$ for $F r_{T}=1.78$ where the transom ventilation was 0.44 .

For transom draft Froude numbers exceeding 1.6 an agreement between CFD and experimental measurements was within the specified error of the experimental results, whereas for lower speeds the numerical simulation predicts a $10-12 \%$ higher water level at the transom.

\subsection{Empirical Prediction}

The empirical approach by Doctors et al. (2007) predicted the dry state at $F_{T}^{*}=2.43$ when considering an infinitely wide transom (2D) and at $F_{T}^{*}=2.56$ when taken the $B_{T} / T_{T}$ ratio into account (3D). Both empirical approaches predict the level of transom ventilation within the experimental error for $F r_{T} \leq 2$ and matched the dry state at a transom draft Froude number less than 1\% (3D) and 3\% (2D) different from the measured value. Between these speeds the empirical formulation underestimated the ventilation state when compared to experimental results. However, this under-prediction is in accordance with the original experiments from which the the regression has been derived. 


\section{Fig05_FIGtransVent.jpg}

Figure 5: State of transom ventilation where 0 means fully wet and unity fully dry with respect to transom Froude number. Results are based on CFD simulation at model and full scale, experimental measurements and empirical predictions of Doctors et al. (2007) with and without taking limited $B_{T} / T_{T}$ values into account.

\subsection{Qualitative Validation of Transom Flow}

The flow features were visualised using stream tracers attached to the model. In the post-processing of the CFD simulations the stream tracers were seeded to correlate to the experimental model set-up. The length and width of the virtual stream tracers were matched with the experimental stream tracers to study if the numerical simulation is capable of predicting flow characteristics that are comparable to the experimentally observes ones.

\subsubsection{Steady Observations}

Two speeds were used to compare the instantaneous flow features between snapshots of the unsteady simulations and model test experiments shown in Figure 6, 7 and 8. In the experiments and simulations the speeds of $V=1.30$ and $1.95 \mathrm{~m} / \mathrm{s}$ correspond to transom draft Froude numbers of $F r_{T}=1.30,1.37$ and $F r_{T}=1.97,2.01$. The difference results from inconsistent transom depths despite identical model length and mass displacement. For the lower speed it can be seen that in the experiment most of the tracers follow the recirculation of the flow with their tips pointing towards the transom, while a few align with the continuing flow and their tips point away from the vessel. The same behaviour can be observed in the image generated by the numerical simulation, especially the point from where the streamlines either point towards the stern or away from it is well predicted in CFD. Additional features of the flow can be observed in Figure 6: the intersection of water level and tank wall, due to capillary deformation of the 
water surface, as marked by (A); the bumpy small-scale wake features due to wave breaking marked by (B); and the distance between the water level around the stern and at the transom has been marked by (C). Subjectively, the numerical approach is capable of replicating these features. For the higher speed shown in Figure 7 the stagnant area as determined by model test experiments is clearly smaller when compared to the lower speed shown in Figure 6. As for the lower speed, most stream tracers are experiencing recirculation, while single ones may follow the main flow. The depression of the free surface (C) at the transom can be seen to be more pronounced. The water level at the tank wall (A), and the turbulent wake structures (B) are well reproduced in CFD compared to the experimental observations.

The bottom view of the stagnant zone has been visualised for $V=1.30 \mathrm{~m} / \mathrm{s}$ and good agreement between the numerical visualisations and experimental results can be seen in Figure 8 . Either the stream tracers appear as straight lines until they start to wiggle and eventually point towards the vessel and indicate recirculation, or they randomly point somewhere due to the unsteadiness of the flow in this area. The distance until the stream tracers start oscillating is comparable between the two images.

\section{Fig06_uwFigV130.jpg}

Figure 6: Side view: Comparison of flow past partially ventilated transom at transom draft Froude number $F r_{T}=1.30$ and 1.37 between snapshots from physical experiment (bottom) and unsteady numerical simulation (top).

\section{Fig07_uwFigV195.jpg}


Figure 7: Profile view: comparison of flow past partially ventilated transom at transom draft Froude number $F r_{T}=1.97$ and 2.01 between snapshots from physical experiment (bottom) and unsteady numerical simulation (top).

\section{Fig08_uwBotFigV130.jpg}

Figure 8: Bottom view: comparison of flow past partially ventilated transom at transom draft Froude number $\mathrm{Fr}_{T}=1.30$ and 1.37 between physical experiment (bottom) and numerical simulation (top).

\subsubsection{Unsteady Observations}

From visual observations of the model test experiments it was seen that the root part of the stream tracers were almost steadily aligned with the flow while the tips underwent random oscillations due to the unsteadiness of the wake. These observations were made in the unsteady RANS simulations too, however they were less pronounced when compared to the experiment. Maki et al. (2006) and Bhushan et al. (2012) predicted a von-Karman-type vortex shedding for transom draft Froude numbers exceeding unity at an infinitely wide transom, but such unsteady behaviour was neither identified in the numerical simulation nor seen in the physical model testing for $F r_{T}>1.0$. In the experiments an unsteady fluctuation for $F r_{T}>2.10$ was seen that could be explained by a von-Karman-type shedding, however it could have also been induced by portions of water that were shed from the rooster tail towards the transom. It is assumed that the relatively low $B_{T} / T_{T}$ ratio influences the flow so that a stable and non-shedding structure builds up for the majority of the speed range below $\mathrm{Fr}_{T}^{*}$. 


\section{Characteristics of Flow Past Transom}

In Section 3.2 it was shown that the state of transom ventilation predicted by the numerical simulation was within the experimental error for $F r_{T}>1.6$ and in Section 3.4.2 the flow structure was found well replicated. Therefore the numerical approach can be used to describe the flow features in more detail and to undertake further investigation. This comprises the visualisation of the flow structure in the stagnant zone past the transom, the change of this structure during the quasi-steady ventilation process and the quantitative change in the state of transom ventilation when full-scale Reynolds numbers are applied.

\subsection{Flow in Stagnant Area}

The number of stream traces used in the post-processing of the simulation was increased to visualise the flow structure with greater resolution (Figure 9 a-d). The light grey colour of the streamlines indicates a reversing fluid that flows towards the hull whereas dark grey represents flow that moves away from the hull. From the profile view (Figure 9 b) it can be seen that a recirculating roller occurs, while the plan view shows that two counter rotating vortical structures are present (Figure $9 \mathrm{c}$ ). In the aft perspective (Figure $9 \mathrm{~d}$ ) it can be seen that the stagnant flow structure points up to the centre plane of the demihull, which is where the rooster tail occurs. Finally, if the flow in the stagnant area is looked at from an angle (Figure 9 a), it can be seen that it forms a single coherent structure that can be best described as a squashed horseshoe vortex. When the speed increases the length and height of the squashed horseshoe decreases, but the principal features remain. The mesh appears to be coarse, but it is capable of resolving the recirculating flow (Figure 10).

Fig09_flowStructure.jpg 
Figure 9: a) Squashed horseshoe structure of the flow inside the stagnant area behind the transom (A) at $F r_{T}=1.66$; b) Profile view indicates the reversing behaviour (B) of the stagnant flow; c) Plan view shows the two counter rotating vortices at the upper side of the stagnant area; d) Aft view indicates the rising streamlines (D) that will potentially form the characteristic rooster tail in the wake.

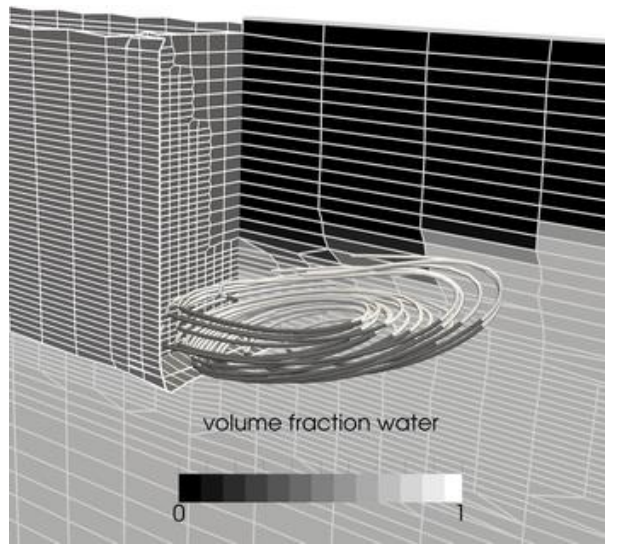

Figure 10: Mesh structure and predicted flow past transom and the distribution of volume fraction at the centre plane of the demihull.

\subsection{Process of Transom Ventilation}

The quasi-steady process of transom ventilation is presented in this section, and in Figure 11, the flow structure, as well as the free surface, is shown. The free surface was assumed to be where the value for volume fraction equals 0.5 . However, when wave breaking happens volume fractions between zero and unity may occur over a wide range of cells and the interface between air and water is not sharp. Therefore the streamlines were scaled with respect to volume fraction, so that a reduced diameter of the streamline indicates wave breaking in the recirculating flow. The recirculating part is represented by white lines, 
while the water moving away from the transom is shown by dark grey lines. It can be seen that the size of the stagnant flow volume reduces from $F r_{T}=1.37-2.01$. It shrinks in height due to the decreasing water level at the transom and consequently in length. At $F r_{T}=1.92,2.01$ it can be seen that the free surface suffers from wave breaking which results in an uncertain interface and a reduced diameter of the recirculating streamlines. At $F r_{T}=2.19$ the value of transom ventilation is 0.88 , which is the highest speed with a partially wet transom and very thin recirculating streamlines indicate strong wave breaking. This behaviour was also seen in the experiment as shown in Figure 12. The white arrow points to a fluid portion that occurs in breaking waves and splashes towards the transom. A majority of the recirculation happens by this kind of wave breaking. It has to be kept in mind that this process is highly unsteady and that all images just present a snapshot of the phenomenon. At $F r_{T}=2.28$ and 2.42 the flow clearly separates and leaves the transom dry. In contrast, in the experiment at $F r_{T}=2.25$ and 2.38 the transom ventilation was 0.91 and 0.95 respectively. This discrepancy may be explained by the reduced size of the flow structures of the breaking wave that are unresolved by the computational mesh. These will shed off from the rooster tail and roll down towards the transom, as characterised by flow regime C in Figure 1. 


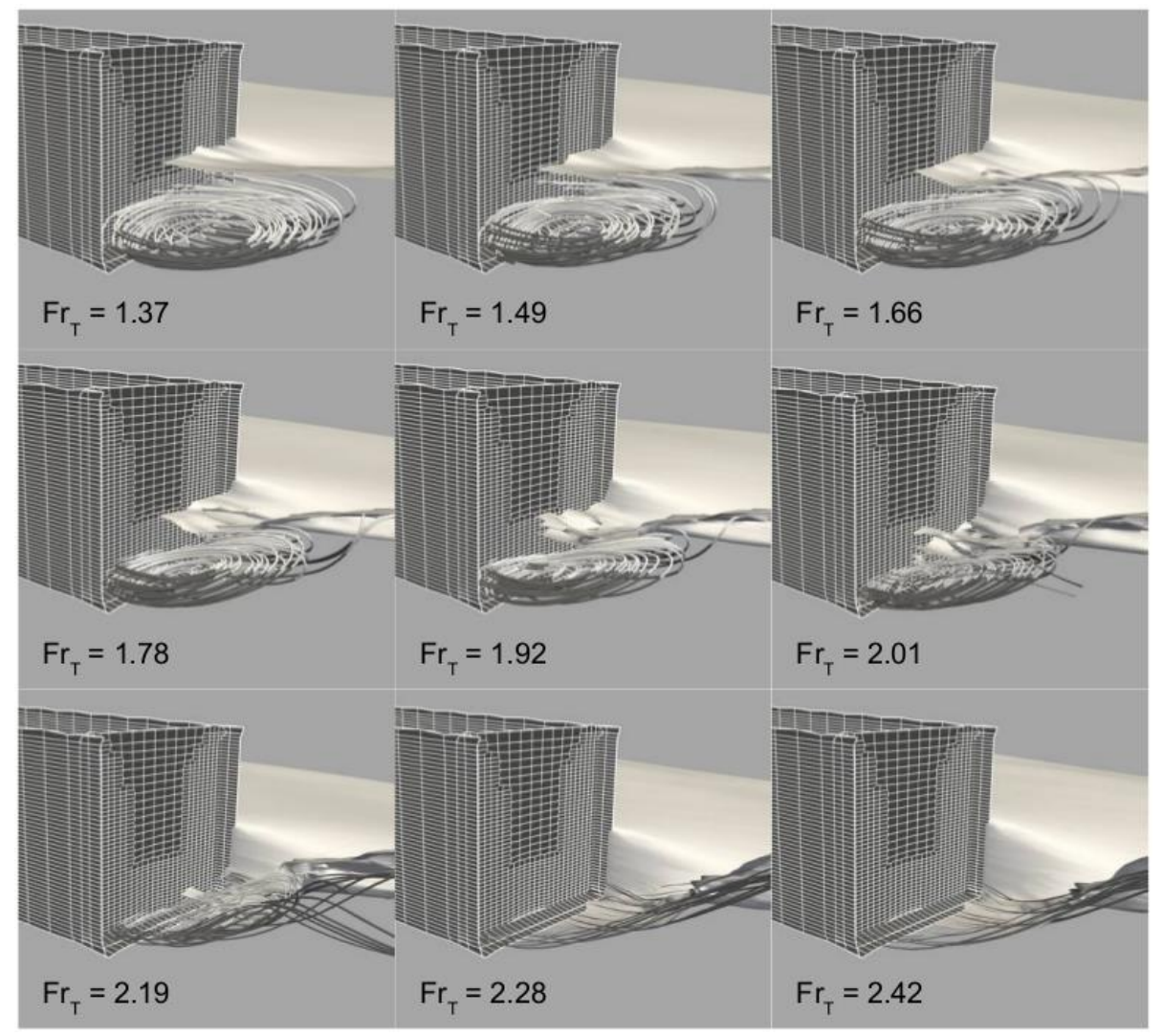

Fig11_ventProcess.jpg

Figure 11: Flow structure and free surface behind the transom undergoing the ventilation process at model scale. White streamlines present recirculating flow and a reduced diameter indicates wave breaking.

\section{Fig12_fluidLump.jpg}

Figure 12: Image of the transom including the built-up of a rooster tail at $F r_{T}=2.19$. The arrow points at a fluid portion that represents breaking flow recirculation. 


\subsection{Results at Full-Scale}

The simulations were repeated at hydrodynamic full scale, where full-scale Reynolds numbers were achieved by altering the fluid viscosity. The results are presented in Figure 5, together with the modelscale results. It can be observed that the transom for $F r_{T}<1.6$ is more ventilated at larger Reynolds numbers and hence the dry state is reached earlier. At transom draft Froude numbers below 1.6 the change in Reynolds number does not influence the ventilation state. With the values from the current investigation it can be concluded that the full-scale transom becomes dry at $F_{T}^{*}=2.2$, in contrast to $F_{T}^{*}=2.4$ in the model-scale simulations.

This difference can be explained by the reduced boundary layer thickness at full-scale Reynolds numbers. Therefore, the full-scale flow induces a lower pressure than the model-scale flow and hence will reduce the water level at the transom to a larger extent. This demonstrates why it may not be feasible to linearly scale ship hydrodynamic properties from model-scale observations to the full-scale ship. Therefore non-linear tools for resistance extrapolation, such as the CFD-based approach in conjunction with model test experiments as postulated in another work of the authors (Haase et al., 2015c), may be superior for accurate full-scale drag prediction when compared to traditional ITTC extrapolation methods.

Finally, the numerical simulation revealed that for the speed range under consideration, the hydrostatic drag due to the transom contributes up to $50 \%$ to the total drag of the vessel at model scale and even up to $70 \%$ for the full-scale ship. 


\section{Conclusions}

This study has shown that the flow in the stagnant area could be best described as a non-shedding squashed horseshoe vortex, which behaves like a recirculating roller at the centre plane of the stagnant zone and two counter rotating vortices at the top of the stagnant zone.

Other researchers predicted a periodic von-Karman vortex shedding from the transom edge for transom draft Froude numbers exceeding unity for transom flows of infinitely wide transoms, or those of Combatant hull forms. However, for the wave-piercing hull form under consideration no such periodic shedding was observed, neither in experiments nor in numerical simulations, which may be due to the three-dimensional nature of the flow. For a transom draft Froude number exceeding 2.2, an unsteady fluctuation occurs, but cannot be clearly identified as the von-Karman-type shedding.

Also, the process of transom ventilation has been visualised in a quasi-steady manner. The transition from a partially wetted state to a fully dry state, including a recirculation in the form of a squashed horseshoe vortex, and breaking waves, just before the fully dry state occurs was shown. These three phenomena of partially wet, breaking recirculation and fully dry obtained through numerical simulation qualitatively agreed to observations from model test experiments.

Furthermore it has been demonstrated that the unsteady RANS-based simulations are capable of quantitatively predicting the flow past a partially ventilated transom for a wave-piercing catamaran hull form. The agreement has been within the experimental error of $4.5 \%$ between numerical predictions and experimental measurements for transom draft Froude numbers exceeding 1.6. This has been achieved on a standard mesh with no additional refinements in the vicinity of the transom. Increasing speed and therefore an increasing transom draft Froude number leads to a reduction in the water level at the transom, until it reaches a dry state at transom Froude number of $F r_{T}=2.50$ as determined in physical model test experiments. The numerical simulation predicted the dry state transom Froude number of 2.42 at model 
scale and at 2.20 at full-scale Reynolds numbers which leads to the conclusion that model-scale results cannot be directly applied to a full-scale ship.

The drag due to the transom stern can be the main contributor to the total drag; in the current study it contributed $50 \%$ at model-scale and even $70 \%$ at full-scale to the total vessel drag. Hence inaccuracies or deviations in modelling the transom and predicting the flow can have a large impact on the total drag force.

Despite the encouraging results of this study, one has to bear in mind that the flow past a transom stern features some highly unsteady small-scale flow features that are neither resolved on a standard mesh, nor by unsteady RANS simulations. Hence the appropriate simulation technique depends on the application and the scope of the study. However, for simulating the water level at the transom and resolving the macro flow features past the transom, the presented method can be considered as being adequately accurate.

\subsection{Recommendations for Future Work}

The effect of a waterjet propulsor or a propeller on the transom ventilation process may be considered, as this will influence the flow around the hull before reaching the transom and therefore the ventilation

process. Furthermore the jet of water leaving the waterjet nozzle will change the flow characteristics in the stagnant zone during non to partially ventilated conditions and potentially the build-up of the rooster tail for partially to fully ventilated conditions. 


\section{Acknowledgements}

The authors would like to thank Konrad Zürcher for his assistance during the model test experiments and providing "his" model for this investigation. Not less we want to express gratitude to the AMC Towing Tank staff and in particular Kirk Meyer for the efforts in visualising the flow. Furthermore we would like to acknowledge A/Prof Kevin Maki (University of Michigan) and Prof Lawrence Doctors (University of New South Wales) for their valuable feedback on parts of this research, and Sara Laffin (University of Michigan) for her editorial efforts.

This research has been conducted as part of a collaborative research project between INCAT, Revolution Design, MARIN, Wärtsilä, and the School of Engineering and the Australian Maritime College at the University of Tasmania. It was supported under Australian Research Council's Linkage Projects funding scheme (project number LP110100080).

\section{References}

S. Bhushan, T. Xing, and F. Stern. Vortical Structures and Instability Analysis for Athena Wetted Transom Flow with Full-scale Validation. Journal of Fluids Engineering, 134 (3): 031201:1-031201:12, 2012.

G. Davidson, T. R. Roberts, S. Friezer, M. R. Davis, N. Bose, G. Thomas, J. Binns, and R. Verbeek. Maximising Efficiency and Minimising Cost in High Speed Craft. In International Conference on Fast Sea Transportation, volume 11, pages 727-734, 2011.

L. J. Doctors, G. J. Macfarlane, and R. Young. A Study of Transom-Stern Ventilation. International Shipbuilding Progress, 54 (2): 135-145, 2007.

A. Eslamdoost, L. Larsson, and R. Bensow. On Transom Clearance. Ocean Engineering, 99: 55-62, 2015.

M. Haase, G. Davidson, S. Friezer, J. Binns, G. Thomas, and N. Bose. On the Macro Hydrodynamic Design of Highly Efficient Medium-speed Catamarans with Minimum Resistance. Transaction of the Royal Institution of Naval Architects, Part A - International Journal of Maritime Engineering, 154 (A3): 131-142, 2012a. 
M. Haase, F. Iliopulos, G. Davidson, S. Friezer, G. Thomas, J. Binns, N. Bose, J. Lavroff, and M. R. Davis. Application of RANSE based simulations for resistance prediction of medium-speed catamarans at different scales. In Proceedings of 18th Australasian Fluid Mechanics Conference, page 270, $2012 \mathrm{~b}$.

M. Haase, G. Davidson, J. Binns, G. Thomas, and N. Bose. Full-Scale Resistance Prediction in Finite Waters â€“â€“ A Study Using CFD Simulation, Model Test Experiments and Sea Trial Measurements. Proceedings of the Institution of Mechanical Engineers, Part M: Journal of Engineering for the Maritime Environment, under review, $2015 \mathrm{a}$.

M. Haase, G. Davidson, S. Friezer, J. Binns, G. Thomas, and N. Bose. Hydrodynamic Hull Form Design Space Exploration of Large Medium-Speed Catamarans Using Full-Scale CFD. Transaction of the Royal Institution of Naval Architects, Part A - International Journal of Maritime Engineering, in press, 2015b.

M. Haase, K. Zürcher, G. Davidson, J. Binns, G. Thomas, and N. Bose. Novel CFD-Based Full-Scale Resistance Prediction for Large Medium-Speed Catamarans. Ocean Engineering, under review, 2015c.

J. B. Hadler, J. L. Kleist, and M. L. Unger. On the Effect of Transom Area on the Resistance of Hi-Speed Monohulls. In Proceedings of 9th International Conference on Fast Sea Transportation, pages 176-183, 2007.

J. B. Hadler, K. M. Cain, and E. M. Singleton. On the Effect of Transom Area on the Resistance of high-Speed Catamaran Hulls. In Proceedings of 10th International Conference on Fast Sea Transportation, pages 573-588, 2009.

K. Hendrickson, G. Weymouth, S. Banerjee, and D. K. P. Yue. Air Entrainment and Multiphase Turbulence in the Bubbly Wake of a Transom Stern. International Shipbuilding Progress, 60 (1): 375-401, 2013.

T. K. Kiss and R. H. Compton. The Effects of Transom Geometry on the Resisitance of Large Surface Combatants. Transactions SNAME, 97, 1989.

C. W. Lin and S. Percival. Free Surface Viscous Flow Computation Around a Transom Stern Ship by Chimera

Overlapping Scheme. In Proceedings of 23rd Symposium on Naval Hydrodynamics, pages 171-183, 2001.

K. J. Maki. Transom Stern Hydrodynamics. PhD thesis, University of Michigan, 2005.

K. J. Maki, L. J. Doctors, R. F. Beck, and A. W. Troesch. Transom-stern Flow for High-speed Craft. Australian Journal of Mechanical Engineering, 3 (2): 191-199, 2006.

J. O’Dea, D. Jenkins, and T. Nagle. Flow Characteristics of a Transom Stern Ship. Technical Report 81/1057, David W. Taylor Naval Ship Research and Development Center, 1981.

A. J. Oving. Resistance Prediction Method for Semi-Planing Catamarans with Symmetrical Demihulls. Technical report, MARIN, 1985.

S. Robards and L. J. Doctors. Transom-Hollow Predicion for High-Speed Displacement Vessels. In Proceedings of 7th International Conference on Fast Sea Transportation, pages A1.19-A1.26, 2003. 
J. E. Rovere. Catamaran Resistance from Tests on a Single Demihull. In Proceedings of 4th International Conference on Fast Sea Transportation, pages 737-741, 1997.

H. Schneekluth and V. Bertram. Ship Design for Efficiency and Economy. Butterworth-Heinemann, 1998.

M. E. Sireli, Insel M., and Ö. Gören. The Effect of Transom Stern on the Resistance of High Speed Craft. In IX. Congress International Maritime Association of Mediterranean, volume I, pages A40-A47, 2000.

A. R Starke, H. C. Raven, and A. van der Ploeg. Computation of Transom-stern Flows using a Steady Free-surfce Fitting RANS Method. In Proceeding of 9th International Conference on Numerical Ship Hydrodynamics, 2007.

R. V. Wilson, P. M. Carrica, and F. Stern. URANS Simulations for a High-speed Transom Stern Ship with Breaking Waves. International Journal of Computational Fluid Dynamics, 20 (2): 105-125, 2006.

D. Wyatt, T. Fu, G. Taylor, E. Terrill, T. Xing, S. Bhushan, T O’Shea, and D. Dommermuth. â€œComparison of Fullscale Experimental Measurements and Computational Predictions of the Transom-stern Wave of the R/V Athena. In Proceedings of 27th Symposium on Naval Hydrodynamics, 2008.

K. Zürcher, N. Bose, J. Binns, G. Thomas, and G. Davidson. Design and Commissioning Tests for Waterjet Self-â€ Propulsion Testing of a Mediumâ€ Speed Catamaran Ferry using a Single Demihull. In Proceedings of the Third International Symposium on Marine Propulsor, pages 97-103, 2013. 